\title{
The Complex Salmonella typhimurium Ghost Cells Play an Additional Role as an Immune Adjuvant
}

\author{
Yeon Jo Ha, Seung Tae Kim, Ho Young Kang ${ }^{2}$, Sang Wan Gal ${ }^{+*}$ and Sam Woong $\mathrm{Kim}^{+*}$ \\ ${ }^{1}$ Department of Pharmaceutical Engineering, Gyeongnam National University of Science and Technology, Jinju 660-758, Korea \\ ${ }^{2}$ Department of Microbiology, Pusan National University, Busan 609-735, Korea
}

Received November 20, 2013 /Revised February 3, 2014 / Accepted February 3, 2014

\begin{abstract}
Ghost cells have been recognized as eliciting humoral and cell-mediated immune responses and have also been predicted to play a role as an immune adjuvant. In this study, we used the intramuscular (IM) route to inject BALB/c mice with four vaccine groups constructed from Salmonella typhimurium ghost (STG) cells originating from different virulent strains and complex STG groups instead of heat-labile toxin (LT)-B, a type of adjuvant. Although the complex STG groups exhibited a response after a short delay, the groups showed final total IgG levels similar to those of the LT-B group, which encodes LT-B from pMMP300. The IgG1 response to the $x 3339$ group was the highest response at 6 weeks, whereas IgG2a responses to the X3339 and JOL389 groups were higher at 6 and 8 weeks compared to those of the LT-B group. The response of vaginal sIgA to the LT-B group was generally higher than that of the other groups, whereas fecal sIgA to the LT-B group exhibited lower responses. Protection to virulent $S$. typhimurium in all groups was above $80 \%$, which was similar to the LT-B group. Taken together, we suggest that STG complex groups can be used as an immune adjuvant instead of LT-B.
\end{abstract}

Key words : Antibody, ghost, intramuscular, labile toxin (LT)-B, Salmonella

\section{서 론}

Salmonella는 gram-negative 통성 혐기성 세균으로서 주로 구강을 통해 중요한 가축 등에 감염되어 위염, 설사, 패혈증 등의 질병을 일으킨다[14]. 또한, Salmonella는 사람에게도 감 염되어 위염, 장티푸스 등의 심각한 질병을 일으키기도 한다 $[5,22,26]$. 특히, S. typhimurium은 사람에게 가장 빈번히 감염 을 일으키는 Salmonella serotype이다[1, 4, 7, 19, 20, 28]. 이들 은 포유동물, 조류, 파충류, 각종 애완동물 및 농업적으로 Salmonella 균이 함유된 유제품, 계란, 육류 등 가축 유래의 식 품이나 가축들의 분노에 의해 오염된 물을 통해 감염되는데, 식품유래의 Salmonella 감염이 이루어지면 48시간 이내에 위염 을 일으키게 된다[12, 17, 18, 23]. Salmonella 감염에 의한 장염 은 연간 2 13억 건의 발병률을 나타내고 있으며, 이 가운데 약 3백만 명 이상이 사망하는 것으로 알려져 있다(http:// www.who.int/ mediacentre/factsheets/fs139/en/) [3].

\footnotetext{
${ }^{\dagger}$ Authors contributed equally.

*Corresponding author

Tel : +82-82-55-751-3393, Fax : +82-82-55-751-3399

E-mail : swkim@gntech.ac.kr (Sam Woong Kim) sangal@gntech.ac.kr (Sang Wan Gal)

This is an Open-Access article distributed under the terms of the Creative Commons Attribution Non-Commercial License (http://creativecommons.org/licenses/by-nc/3.0) which permits unrestricted non-commercial use, distribution, and reproduction in any medium, provided the original work is properly cited
}

Bacterial ghost (BG)는 용균 과정에서 자연 상태의 형태를 가지고 있기 때문에 모든 주요 면역 자극 요소가 잘 보존되어 있다[15]. 이들 요소는 병원균과 연관된 분자 패턴(pathogenassociated molecular patterns; PAMPs)으로서 언급되며, 리 포폴리사카라이드(LPS), monophosphoryl lipid A (MPL), 펩 티도글리칸, 편모 등을 포함한다. PAMPs는 패턴 인식 수용체 (toll like receptor; TLR)에 의해 인식되기 때문에 선천적 면역 반응을 유발한다. 따라서 BG로 유도된 모든 박테리아는 첫 반응으로서 선천적 면역 반응을 유발한다[15]. 또한, $\mathrm{BG}$ 는 실 험동물에서 체액성 및 세포성 면역 응답을 유도하는 매우 효 과가 우수한 면역보강제로서의 특성이 있다[24].

E. coli의 heat-labile enterotoxin (LT)는 면역응답의 증가를 유도하는 성질에 의해 광범위하게 연구되어져 오고 있다[11]. LT는 효소적으로 활성이 있는 A subunit (LT-A)과 GM1 ganglioside receptor에 결합하는 비독성 B subunit (LT-B)로 구성 된다. LT-B가 포유동물 세포표면에 GM1과 안정한 상호연결 은 동시에 투여된 단백질의 흡수를 돕는 것으로 보이며, 점막 과 세포성 면역을 상승시키기 때문에 면역보강제로서 넓게 사용되고 있다[9, 10].

따라서 본 연구에서는 BG가 heat labile toxin-B (LT-B)를 대체할 수 있는 능력이 있는가를 평가해 보았고, 그 결과 복합 BG 균주가 LT-B를 대체할 수 있는 것으로 나타났다. 
Table 1. Bacterial strains and plasmids used in this study

\begin{tabular}{|c|c|c|}
\hline Strains and plasmids & Descriptions & References \\
\hline \multicolumn{3}{|l|}{ E.coli } \\
\hline Top10 & $\begin{array}{l}\text { F-mcrA (mrr-hsdRMS-mcrBC) } \Phi 80 \text { lacZ } \triangle \text { M15 } \triangle \text { lacX74 nupG recA1 araD139 } \\
\left.\Delta \text { (ara-leu)7697 galE15 galK rpsL (Str }{ }^{\mathrm{R}}\right) \text { endA1 }\end{array}$ & Invitrogen \\
\hline DH5a & $\begin{array}{l}\text { fhuA2 } \Delta(\text { argF-lacZ)U169 phoA glnV44 } \Phi 80 \Delta(\text { lacZ)M15 gyrA96 recA1 relA1 } \\
\text { endA1 thi-1 hsdR17 }\end{array}$ & Lab stock \\
\hline$x 6212$ & $\begin{array}{l}\Phi \text { 80d lacZ } \triangle \mathrm{M} 15 \text { deoR } \triangle(\text { lacZYA-argF }) \text { U169 supE441 gyrA96 recA1 relA1 } \\
\text { endA1 asdA4 } \triangle \text { zhf-2::Tn10 hsdR17 }\left(\mathrm{R}^{-} \mathrm{M}^{+}\right)\end{array}$ & Lab stock \\
\hline \multicolumn{3}{|l|}{ Salmonella } \\
\hline S. typhimurium $\times 3339$ & wild-type strain SL1344, hisG rpsL & Lab stock \\
\hline S. typhimurium $\times 8554$ & c3339 asdA16 & Lab stock \\
\hline S. typhimurium JOL389 & wild-type strain isolated from swine in South Korea & $\begin{array}{l}\text { Chonbuk National } \\
\text { University }\end{array}$ \\
\hline \multicolumn{3}{|l|}{ Plasmids } \\
\hline pMMP184 & a derivative of pYA3342 carrying cI857 PR E ara and PR ompA TM & Lab stock \\
\hline pMMP300 & a derivative of pMMP184 carrying LT-B & Lab stock \\
\hline
\end{tabular}

\section{재료 및 방법}

\section{사용된 균주, 플라스미드 및 유전자 조작}

사용된 균주 및 플라스미드는 Table 1에 정리되어 있다. $E$. coli 및 Salmonella strain은 현재 연구실에서 보관중인 균주 또 는 전북대학교 수의과대학에서부터 분양받은 균주를 사용하 였다.

본 실험에 사용된 플라스미드의 $E . c o l i$ 에 형질전환은 $\mathrm{CaCl}_{2}$ 처리를 경유하여 열 충격 방법으로 실시하였고, Salmonella에 형질전환은 전기천공법(electroporation)에 의해 실시하였다 [25].

\section{고스트화 및 생균수 측정}

고스트화 및 생균수를 측정하기 위해 전배양된 X8554 [pMMP184] 균주 및 기타 살모넬라 배양액을 $100 \mathrm{ml} \mathrm{LB}$ 배지 에 $1 / 100$ 로 접종하여 $28^{\circ} \mathrm{C}$ 에서 $24 \mathrm{~h}$ 배양하였다. 배양이 완료 된 후 배양된 액을 멸균된 원심분리관에 첨가하여 $4,500 \times \mathrm{g}$ 로 $4{ }^{\circ} \mathrm{C}$ 에서 20 분간 원심분리하여 배양 상등액을 완전히 제거하 였다. 침전된 세포에는 배양액과 동일한 양의 phosphate buffered saline (PBS) 완충액을 첨가한 후 위와 동일한 조건으로 2회에 걸쳐 원심분리하여 불순물을 완전히 제거하였다. 처리 된 세포에 신선한 $\mathrm{M} 9\left(4 \mathrm{~g}\right.$ glucose, $12.8 \mathrm{~g} \mathrm{Na}_{2} \mathrm{HPO}_{4} 7 \mathrm{H}_{2} \mathrm{O}$, $3 \mathrm{~g} \mathrm{KH}_{2} \mathrm{PO}_{4}, 0.5 \mathrm{~g} \mathrm{NaCl}_{1} 1 \mathrm{~g} \mathrm{NH}_{4} \mathrm{Cl}, 0.49 \mathrm{~g} \mathrm{MgSO}_{4}$ ) 배지를 첨가하여 $42^{\circ} \mathrm{C}$ 에서 계속 배양하면서 고스트화를 유도하였고, 생균수는 적정 시간 간격으로 샘플링을 수행하여 측정하였다.

고스트 카세트를 운반하지 않는 S. typhimurium X3339 및 S. typhimurium JOL389와 같은 균주는 E protein과 유사한 역 할을 수행하는 fosfomycin (100 ug/ml medium)으로 E protein의 용균과정과 동일한 조건에서 용균을 유도하였다. 즉, 각 균주를 위와 동일한 조건으로 성장을 유도하여 fosfomycin
를 첨가하여 $42^{\circ} \mathrm{C}$ 에서 용균을 유도하였다. 고스트화가 완료된 고스트 세포는 원심분리관에 첨가하여 $4,500 \times g$ 로 $4{ }^{\circ} \mathrm{C}$ 에서 20 분간 원심분리하여 배양 상등액을 완전히 제거한 후, 고스트 농축액을 제조하여 직접적으로 사용하거나 동결건조를 실시 하였다.

\section{고스트 세포의 마우스 vaccination}

제조된 고스트 세포는 농도별로 희석하여 일주일간 순화된 $\mathrm{BALB} / \mathrm{c}$ 마우스에 근육으로 접종하였다. 접종량은 근육으로 $1 \times 10^{8} \mathrm{CFU} / \mathrm{ml}$ 에 의해 접종하였다. 접종하기 전에 4 시간 이상 절수 및 절식을 시켰고 접종 후 1 시간 후 음수 및 사료를 제공 하였다. 접종을 실시한 후 8 주 동안 마우스를 관찰하였고 혈액 중의 면역글로불린 함량을 측정하기 위한 혈액의 채취는 2 , $4,6,8$ 주에 눈 정맥을 통해 실시하였다. 또한 분비액 중에 $\operatorname{sgA}$ 를 측정하기 위해 질세척액과 분변을 $2,4,6,8$ 주에 채취하였 다. 질 세척액은 $100 \mathrm{ul} \mathrm{PBS} \mathrm{buffer을} \mathrm{질에} \mathrm{투여하여} \mathrm{채취하였}$ 고, 분변은 적정량을 회수한 후 PBS buffer로 10배 희석하고 파쇄하여 사용하였다.

\section{ELISA (Enzyme-linked immunosorbent assay)}

S. typhimurium LPS를 $200 \mathrm{ng} / 100 \mathrm{ul}$ 의 농도로 $0.05 \mathrm{M}$ carbonate 용액 $\left(\mathrm{pH}\right.$ 9.6)에 넣어서 $4^{\circ} \mathrm{C}$ 에서 overnight 시키고 microtiter plate의 표면에 항원으로 코팅시켰다. 코팅용액을 버 리고 PBS (pH 7,4) 완충액으로 1회 세척을 수행하였다. PBS (pH 7.4) 완충액을 완전히 제거한 후 $1 \%$ skim milk을 포함된 PBS 완충 용액으로 상온에서 30 분간 blocking 시켰다. Blocking 용액을 버리고 샘플[혈액(1:50), 분변(1:2), 질분비액 (1:2)]을 포함하는 PBS 완충액을 첨가하여 $37^{\circ} \mathrm{C}$ 에서 2시간 반 응시켰다. 반응이 종료된 후 $\mathrm{PBS}$ (pH 7.4) 완충액으로 2회 세 척을 수행하였다. PBS $(\mathrm{pH} 7.4)$ 완충액을 완전히 제거한 후, 
2차 항체인 goat anti-mouse IgG (1:2,000; Southern Biotech), goat anti-mouse lgG1 (1:2,000; Southern Biotech), goat anti-mouse IgG2a (1:2,000; Southern Biotech), goat anti-mouse $\operatorname{IgA}$ (1:2000; Southern Biotech)을 첨가하여 상온에서 2시간 반응시켰다. 반응이 종료된 후, $\mathrm{PBS}(\mathrm{pH} 7.4)$ 완충액으로 2 회 세척을 실시하였다. PBS (pH 7.4) 완충액을 완전히 제거한 후 반응 기질 2,2'-azino-bis (3-ethylbenzthiazoline-6- sulphonic acid) (ABTS)를 포함하는 용액에서 10-90분 동안 반응시켰다. $0.1 \% \mathrm{SDS}$ 로 반응을 정지시킨 후 ELISA reader로 파장 405 $\mathrm{nm}$ 에서 발현 정도를 관찰하였다.

\section{고스트 세포의 살모넬라균에 대한 보호능력 확인}

고스트 세포가 독력이 있는 살모넬라균에 대한 보호능력을 관찰하기 위해서 다음과 같이 도전실험을 실시하였다. 근육으 로 $1 \times 10^{8} \mathrm{CFU} / \mathrm{ml}$ 고스트 세포를 접종하고 동량으로 2주 간격 으로 추가 접종하였다. 고스트 세포 접종 10주 후에 S. typhimurium $\mathrm{c} 3339$ 를 $1.2 \times 10^{6} \mathrm{CFU}$ 의 농도로 경구 투여하였다. 접종 하기 전에 4 시간 이상 절수 및 절식을 시켰고 접종을 완료하고 1 시간 후 음수 및 사료를 제공하였다. 도전 실험을 실시한 후 에 4주 동안 마우스를 관찰하였다. 이 연구에 사용된 동물 실 험은 한국동물보호위원회의 가이드라인에 따른 경남과학기 술대학교 동물윤리위원회의 승인하여 수행되었다(ACE20100730-0002).

\section{결과 및 고찰}

\section{백신화에 따른 총lgG면역 효과}

고스트 백신을 제조하기 위해 박테리오파아지 람다 c1857 $\mathrm{P}_{\mathrm{R}}$ 과 $\Phi \mathrm{X} 174 E$ 유전자를 융합한 체계를 많이 활용하고 있다
[27]. 본 연구에서도 이 $c 857 \mathrm{P}_{\mathrm{R}:: E}$ 체계를 도입하여 고스트화 를 유도하였다. 단, 본 연구에서는 기존의 균주의 선별을 위해 사용한 항생제 마커 대신에 host-balanced lethal system으로 사용되는 aspartate semialdehyde dehydrogenase (asd)를 도 입하여 pMMP184를 구축하였다(unpublished data).

일반적으로 LT-B는 그 효능이 우수한 것으로 평가되어 목 적동물의 면역 증강을 위한 면역보강제로서 많이 사용되고 있다 $[2,13,21]$. BG는 일반적으로 면역반응유발 기능뿐만 아 니라 면역보강제로서의 역할이 있는 것으로 알려져 있다[24]. 따라서 본 연구에서는 면역보강제인 LT-B에 대해 BG가 기능 을 대체할 수 있는지를 알아보기 위해, 면역보강제인 LT-B와 독력이 강한 균주인 S. typhimurium X3339 및 S. typhimurium JOL389로부터 유도된 BG에 대해 BG의 비교 실험을 수행하였 다. S. typhimurium $\times 3339$ 및 S. typhimurium JOL389는 각각 $3.5 \times 10^{5} \mathrm{CFU} / \mathrm{ml}$ 및 $3.76 \times 10^{5} \mathrm{CFU} / \mathrm{ml}$ 의 LD50 값들을 나타내 는 강력한 독력을 유도하는 균주들이다(unpublished data). Fig. 1에서 보여지는 바와 같이 총 IgG 함량 변화는 LT-B을 유지하는 B 그룹에서 4 주차에 약간 먼저 상승되는 경향을 보 였지만, 6주 이후에는 S. typhimurium $\times 3339$ 및 S. typhimurium JOL389와 특별한 차이가 없는 것으로 나타났다. 그러므로 total IgG 수준에서만 본다면 LT-B을 유지하는 X8554 [pMMP 300]은 S. typhimurium X3339 및 S. typhimurium JOL389로 대 체가 가능한 것으로 판단된다.

\section{$\operatorname{lgG} 1, \lg G 2 a$ 및 $\operatorname{sg} A$ 면역응답}

면역글로블린 $\mathrm{IgG}$ 의 subtype인 $\mathrm{IgG1}$ 과 $\mathrm{IgG} 2 \mathrm{a}$ 의 생성은 $\mathrm{Th} 2$ 와 Th1에 의해 촉진되어지고, 각각 체액성 면역과 세포 매개 면역 응답을 유발하도록 한다 $[6,10,16]$. 체액성 면역 및 세포매개면역반응을 알아보기 위해 IgG1 및 IgG2a를 분석하

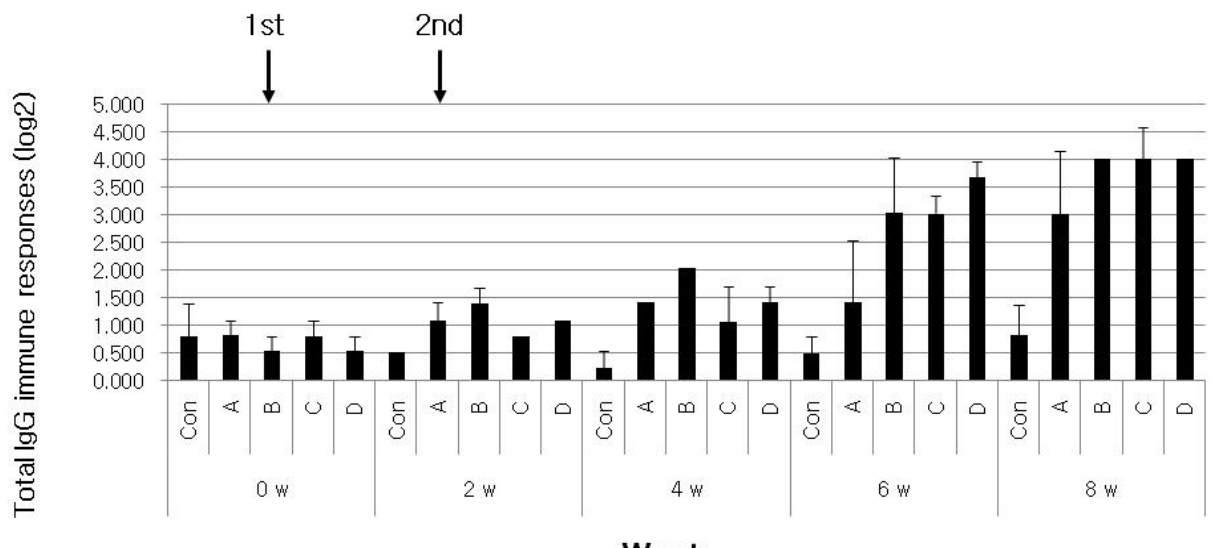

Week

Fig. 1. Total IgG immune responses according to ghost strains via IM route of BALB/c. LPS and total of 2 'Ab were treated for $2 \mathrm{~h}$ at room temperature by $2 \mathrm{ug} / \mathrm{ml}$ concentration and by 1:2,000 ratio, respectively. The treated solutions were measured at $405 \mathrm{~nm}$ by ELISA reader. X- and Y-axes indicate week post injection and immune response by log value, respectively. Con; IM administration by only PBS, A; c8554 [pMMP184], B; c8554 [pMMP184] + c8554 [pMMP300], C; c8554 [pMMP184] + c3339, D; c8554 [pMMP184] + JOL389. 


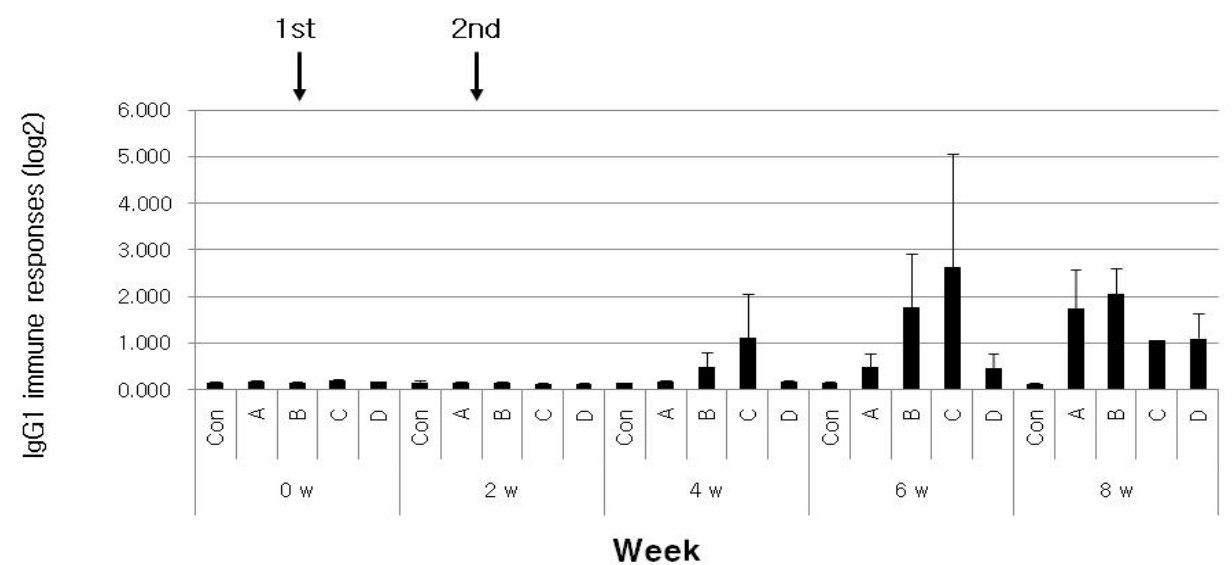

Fig. 2. IgG1 immune responses according to ghost strains via IM route of BALB/c. LPS and total of 2 'Ab were treated for $2 \mathrm{~h}$ at room temperature by $2 \mathrm{ug} / \mathrm{ml}$ concentration and by 1:2,000 ratio, respectively. The treated solutions were measured at $405 \mathrm{~nm}$ by ELISA reader. X- and Y-axes indicate week post injection and immune response by log value, respectively. Con; IM administration by only PBS, A; X8554 [pMMP184], B; x8554 [pMMP184] + x8554 [pMMP300], C; x8554 [pMMP184] + x3339, D; X8554 [pMMP184] + JOL389.

였다. 그 결과 Fig. 2에서 보여지는 바와 같이 $\mathrm{IgG1}$ 의 경우는 X8554 [pMMP184]/X8554 [pMMP300] 그룹에서 4주차부터 $\mathrm{IgG1}$ 이 감지되어 x8554 [pMMP184]/x3339보다는 낮게 반응 한 반면에 X8554 [pMMP184]/JOL389보다 전반적으로 높게 형성되는 것으로 나타났다. 그러나 IgG2a의 경우는 [pMMP 184]/ X8554 [pMMP300] 그룹이 높은 독력 그룹보다 낮은 것 으로 나타났다(Fig. 3). 즉, 백신 투여 후 6주차부터 면역능력이 감지되었으며, X8554 [pMMP184]/X8554 [pMMP300] 그룹보 다 x8554 [pMMP184]/ x3339나 x8554 [pMMP184]/JOL389 에서 높게 감지되는 것이 관찰되었다.

질 sIgA에서는 LT-B그룹보다 독력 그룹에서 전반적으로 낮 게 감지되었지만(Fig. 4), 분변 $\mathrm{sIgA}$ 는 S. typhimurium X3339나
S. typhimurium JOL389가 첨가된 실험구에서 보다 높은 $\operatorname{sgA}$ 가 4 8주차에서 관찰되었다(Fig. 5). 이상의 결과를 종합해 보 면, LT-B 대체 그룹은 체액성, 세포매개면역반응, $\operatorname{sgA}$ 에 대한 면역응답에 LT-B를 대체하여 사용할 수 있는 것으로 제의된다.

\section{면역보강제의 대체 사용시 독력균주에 대한 마우스 보호효과}

S. typhimurium $\times 3339$ 을 이용한 도전실험결과, 대조구는 $50 \%$ 의 치사율을 보였지만, 단일균주 백신 그룹인 X8554 [pMMP184], x8554 [pMMP184]/x8554 [pMMP300] 및 x8554 [pMMP184]/JOL389는 대조구보다 약 30\%의 보호효과가 높 은 것으로 관찰되었다(Fig. 6). 그러나 X8554 [pMMP184]/X 3339는 백신화 초기에 대부분의 균주에서 폐사가 유도되는

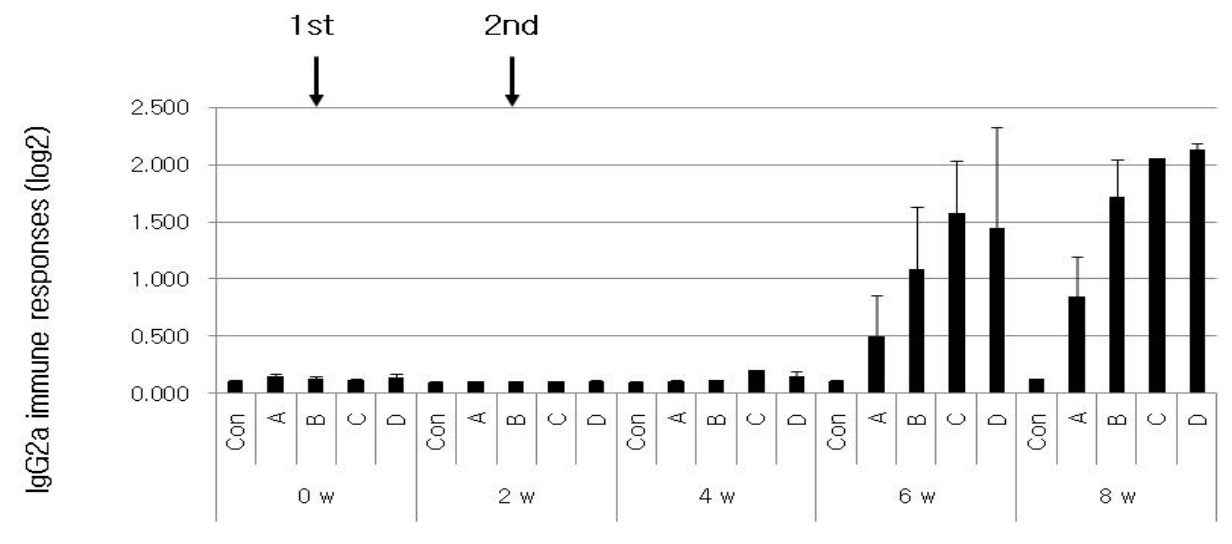

Week

Fig. 3. IgG2a immune responses according to ghost strains via IM route of BALB/c. LPS and total of 2 'Ab were treated for 2 $\mathrm{h}$ at room temperature by $2 \mathrm{ug} / \mathrm{ml}$ concentration and by 1:2,000 ratio, respectively. The treated solutions were measured at $405 \mathrm{~nm}$ by ELISA reader. X- and Y-axes indicate week post injection and immune response by log value, respectively. Con; IM administration by only PBS, A; X8554 [pMMP184], B; X8554 [pMMP184] + X8554 [pMMP300], C; X8554 [pMMP184] + X3339, D; X8554 [pMMP184] + JOL389. 


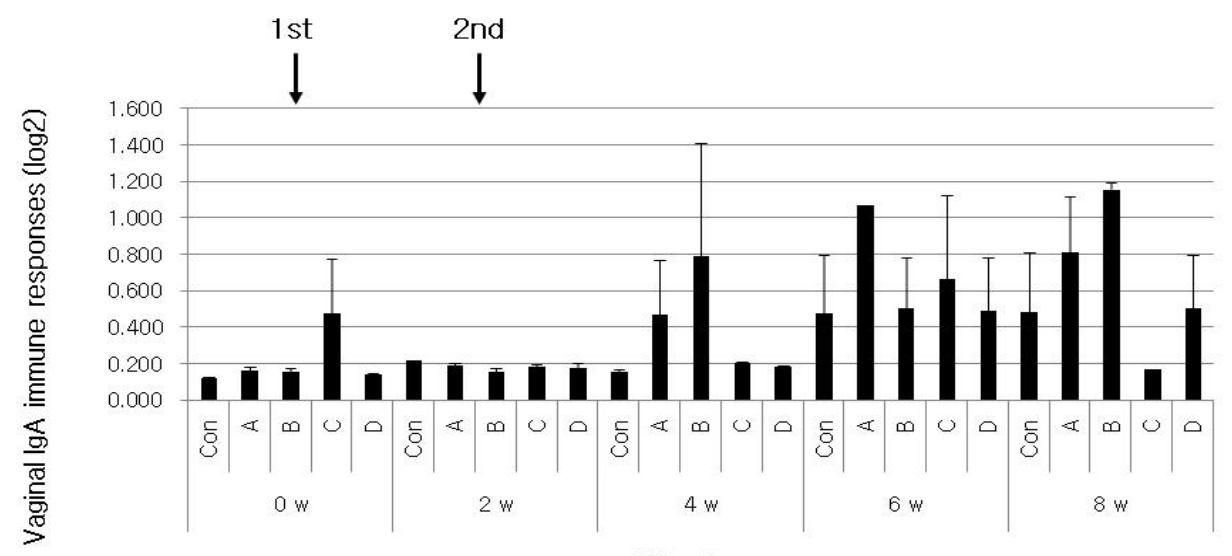

Week

Fig. 4. Vaginal IgA immune responses according to ghost strains via IM route of BALB/c. LPS and total of 2 'Ab were treated for $2 \mathrm{~h}$ at room temperature by $2 \mathrm{ug} / \mathrm{ml}$ concentration and by 1:2,000 ratio, respectively. The treated solutions were measured at $405 \mathrm{~nm}$ by ELISA reader. X- and Y-axes indicate week post injection and immune response by log value, respectively. Con; IM administration by only PBS, A; X8554 [pMMP184], B; x8554 [pMMP184] + x8554 [pMMP300], C; x8554 [pMMP184] + x3339, D; X8554 [pMMP184] + JOL389.

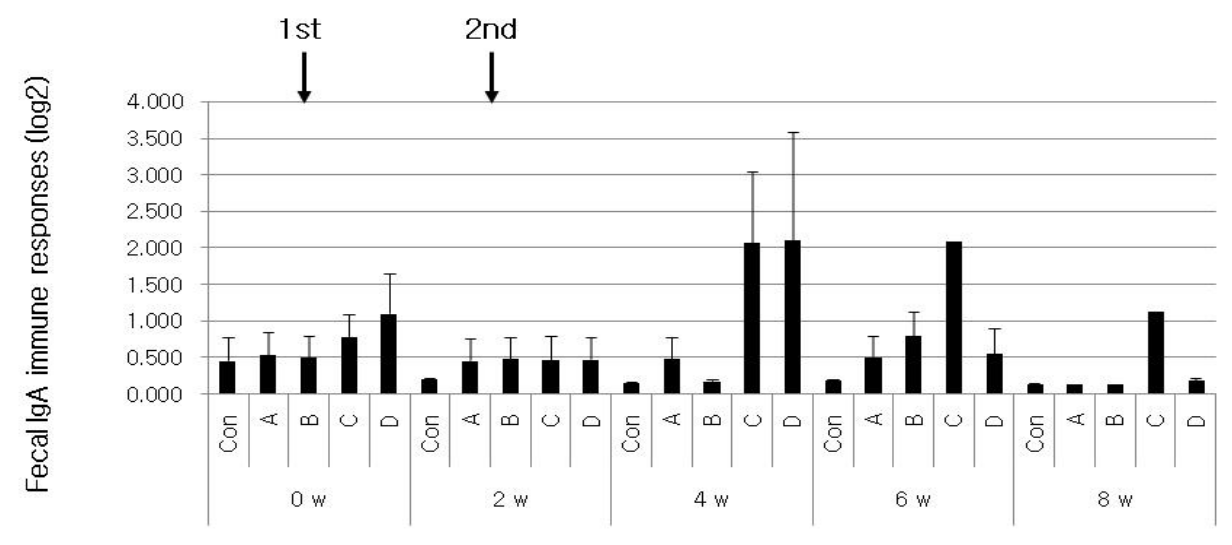

Week

Fig. 5. Fecal IgA immune responses according to ghost strains via IM route of BALB/c. LPS and total of 2 'Ab were treated for $2 \mathrm{~h}$ at room temperature by $2 \mathrm{ug} / \mathrm{ml}$ concentration and by 1:2,000 ratio, respectively. The treated solutions were measured at $405 \mathrm{~nm}$ by ELISA reader. X- and Y-axes indicate week post injection and immune response by log value, respectively. Con; IM administration by only PBS, A; X8554 [pMMP184], B; X8554 [pMMP184] + X8554 [pMMP300], C; X8554 [pMMP184] + x3339, D; x8554 [pMMP184] + JOL389.

관계로 정확한 결과를 획득하지 못했지만, X8554 [pMMP184]/ JOL389의 경향성으로 보아 x8554 [pMMP184]/ X8554 [pMMP 300] 그룹의 대체가 가능한 것으로 추정된다.

\section{감사의 글}

논문은 농림수산식품부 (농림, 식품, 수산)기술개발사업의 지원사업으로 수행된 연구임(110050033HD110).

\section{References}

1. Angulo, F. and Swerdlow, D. L. 1999. Epidemiology of hu- man Salmonella enterica serovar Enteritidis infections in the United States. pp. 33-41. In: Saed, A. M., Gast, R. K., Potter, M. E. and Wall, P. G. (eds.), Salmonella enterica serovar Enteritidis in Humans and Animals. Iowa State University Press.

2. Chaudhari, A. A. and Lee, J. H. 2013. Evaluation of the adjuvant effect of Salmonella-based Escherichia coli heat-labile toxin B subunits on the efficacy of a live Salmonella-delivered avian pathogenic Escherichia coli vaccine. Avian Pathol 42, 365-372.

3. Coburn, B., Grassl, G. A. and Finlay, B. B. 2007. Salmonella, the host and disease: a brief review. Immunol Cell Biol 85, 112-118.

4. Cogan, T. A. and Humphrey, T. J. 2003. The rise and fall 


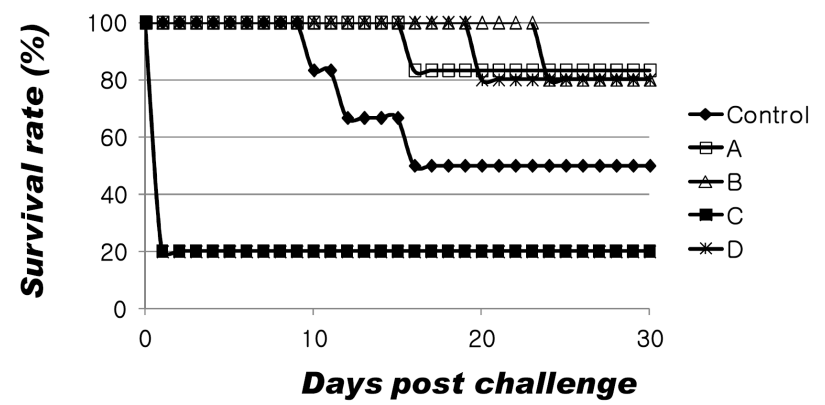

Fig. 6. Challenge test to BALB/c vaccinated via IM according to ghost strains. The virulent $S$. typhimurium $\times 3339$ were orally administrated by $1.2 \times 10^{6} \mathrm{CFU}$ at 2 week post twice administration by ghost strains. The challenged mice were observed for 4 weeks.

of Salmonella enteritidis in the UK. J Appl Microbiol 94, 114S-119S.

5. Cowden, J. M., Lynch, D., Joseph, C. A., O'Mahony, M., Mawer, S. L., Rowe, B. and Bartlett, C. L. 1989. Case-control study of infections with Salmonella enteritidis phage type 4 in England. BMJ 299, 771-773.

6. DeKruyff, R. H., Rizzo, L. V. and Umetsu, D. T. 1993. Induction of immunoglobulin synthesis by $\mathrm{CD} 4+\mathrm{T}$ cell clones. Semin Immunol 5, 5421-5430.

7. Fantasia, M., Filetici, E., Anastasio, M. P., Marcozzi, M. D., Gramenzi, M. P. and Aureli, P. 1991. Italian experience in Salmonella enteritidis 1978-1988: Characterization of isolates from food and man. Int $J$ Food Microbiol 12, 353-362.

8. Fingerut, E., Gutter, B., Goldway, M., Eliahoo, D. and Pitcovski, J. 2006. B subunit of E. coli enterotoxin as adjuvant and carrier in oral and skin vaccination. Vet Immunol Immunopathol 112, 253-263.

9. Freytag, L. C. and Clements, J. D. 2005. Mucosal adjuvants. Vaccine 23, 1804-1813.

10. Gor, D. O., Rose, N. R. and Greenspan, N. S. 2003. Th1-Th2: a procrustean paradigm. Nat Immunol 4, 503-505.

11. Hajishengallis, G., Arce, S., Gockel, C. M., Connell, T. D. and Russell, M. W. 2005. Immunomodulation with enterotoxins for the generation of secretory immunity or tolerance: application for oral infections. J Dent Res 84, 1104-1116.

12. Humphrey, T. J. 1999. Contamination of eggs and poultry meat with Salmonella enterica serovar Enteritidis. pp. 183-192. In: Saeed, A. M., Gast, R. K. and Wall, P. G. (eds.), Salmonella enterica serovar Enteritidis in Humans and Animals; Pathogenesis and Control. Iowa State University Press.

13. Jeon, B. W., Nandre, R. M. and Lee, J. H. 2013. Oral immunization with an attenuated Salmonella Gallinarum mutant as a fowl typhoid vaccine with a live adjuvant strain secreting the B subunit of Escherichia coli heat-labile enterotoxin. BMC Vet Res 6, 96-104.

14. Jones, B. D. and Falkow, S. 1996. Salmonellosis: host immune responses and bacterial virulence determinants. Annu Rev Immunol 14, 533-561.

15. Langemann, T., Koller, V. J., Muhammad, A., Kudela, P.,
Mayr, U. B. and Lubitz, W. 2010. The Bacterial Ghost platform system: production and applications. Bioeng Bugs 1, 326-336.p

16. Li, Y., Wang, S., Xin, W., Scarpellini, G., Shi, Z., Gunn, B., Roland, K. L. and Curtiss, R. 3rd. 2008. A sopB deletion mutation enhances the immunogenicity and protective efficacy of a heterologous antigen delivered by live attenuated Salmonella enterica vaccines. Infect Immun 76, 5238-5246.

17. Lu, S., Manges, A. R., Xu, Y., Fang, F. C. and Riley, L. W. 1999. Analysis of virulence of clinical isolates of Salmonella enteritidis in vivo and in vitro. Infect Immun 67, 5651-5657.

18. Meyer, H. 1999. Animals as sources of infections in humans-salmonellosis. Dtsch Tierarztl Wochenschr 106, 344-351.

19. Mishu, B., Koehler, J., Lee, L. A., Rodrigue, D., Brenner, F. H., Blake, P. and Tauxe, R. V. 1994. Outbreaks of Salmonella enteritidis infections in the United States, 1985-1991. J Infect Dis 169, 547-552.

20. Munro, D. S., Girdwood, R. W. A. and Reilly, W. J. 1999. Salmonella enterica serovar Enteritidis in Scotland. pp. 27-31. In: Saed, A. M., Gast, R. K., Potter, M. E. and Wall, P. G. (eds.), Salmonella enterica serovar Enteritidis in Humans and Animals. Iowa State University Press.

21. Nandre, R. M., Jawale, C. V. and Lee, J. H. 2013. Enhanced protective immune responses against Salmonella Enteritidis infection by Salmonella secreting an Escherichia coli heat-labile enterotoxin B subunit protein. Comp Immunol Microbiol Infect Dis 36, 537-548.

22. Nastasi, A., Mammina, C., Piersante, G. P., Robertazzo, M. and Caruso, P. 1998. A foodborne outbreak of Salmonella enteritidis vehicled by duck and hen eggs in southern Italy. New Microbiol 21, 93-96.

23. Palmer, S., Parry, S., Perry, D., Smith, R., Evans, M., Nehaul, L., Roberts, R., Walapu, M. and Wright, D. 2000. The role of outbreaks in developing food safety policy: population based surveillance of Salmonella outbreaks in Wales 1986.98. Epidemiol Infect 125, 467-472.

24. Riedmann, E. M., Kyd, J. M., Cripps, A. W. and Lubitz, W. 2007. Bacterial ghosts as adjuvant particles. Expert ReV Vaccines 6, 241-253.

25. Sambrook, J., Fritsch, E. F. and Maniatis, T. 1989. Molecular Cloning, A Laboratory Manual. 2nd eds., Cold Spring Harbor Laboratory. Press, Cold Spring Harbor, NY.

26. Tansel, O., Ekuklu, G., Otkun, M., Otkun, M. T., Akata, F. and Tugrul, M. 2003. A food-borne outbreak caused by Salmonella enteritidis. Yonsei Med J 44, 198-202.

27. Tabrizi, C. A., Walcher, P., Mayr, U. B., Stiedl, T., Binder, M., McGrath, J. and Lubitz, W. 2004. Bacterial ghosts-biological particles as delivery systems for antigens, nucleic acids and drugs. Curr Opin Biotechnol 15, 530-537.

28. Tschape, H., Liesegang, A., Gericke, B., Prager, R. and Rabsch, W. 1999. Ups and downs of Salmonella enterica serovar Enteritidis in Germany. pp. 51-61. In: Saed, A. M., Gast, R. K., Potter, M. E. and Wall, P. G. (eds.), Salmonella enterica serovar Enteritidis in Humans and Animals. Iowa State University Press. 


\section{초록 : 면역보강제로서 부가적인 역할을 가지는 복합 살모넬라 타이피무리움 고스트 세포}

하연조 $\cdot$ 김승태 $\cdot$ 갈상완 $*$ 김삼웅*

(경남과학기술대학교 제약공학과)

고스트 백신/LT-B 그룹과 고스트 백신 복합 균주를 각각 구강으로 투여했을 때, 복합고스트백신 그룹은 LT-B와 유사 한 면역 보강제로서 역할을 수행할 수 있는 것으로 나타났다. 따라서 독력이 다른 살모넬라 균주와 LT-B을 대체하는 복합 균주 군을 조성하여 intramuscle (IM)로 주사했다. 그 결과, 복합균주 군은 LT-B을 운반하는 pMMP300과 유사한 총 IgG 함량 변화를 보였다. IgG1과 IgG2a는 LT-B 그룹과 유사한 면역 응답을 보였다. 질 $\mathrm{sIgA}$ 는 LT-B와 약간 차이가 나타났지만, 전반적으로 낮은 면역응답을 보인 반면에, fecal sIgA는 LT-B보다 높은 면역 응답을 보였다. 독력 살모넬라 에 대한 보호효과는 대조구보다 $30 \%$ 높은 수치를 나타내었고, LT-B와 유사한 결과를 보였다. 이상의 결과로 볼 때, 살모 넬라 복합균주는 면역보강제 LT-B를 대체할 수 있는 역할을 수행하는 것으로 추정된다. 